\title{
Tillage Practices in the Context of Climate Change and a Sustainable Viticulture
}

\author{
Alina DOBREI, Eleonora NISTOR, Florin SALA, Alin DOBREI* \\ Banat's University of Agricultural Sciences and Veterinary Medicine "King Michael Iof Romania" from Timisoara, Faculty of Horticulture and Forestry, 119 Calea Aradului \\ 300645Timisoara,Romania; ghitaalina@yahoo.com;nisnora@yahoo.com;florin_sala@yahoo.com; alin1969@yahoo.com (*correspondingauthor)
}

\begin{abstract}
The aim of this study was to identify the most appropriate options for maintenance of soil in vineyards located on flat land or mild slopes, and soils with a medium or high fertility. Tillage in the vineyard is carried out to preserve the soil loosening, for maintaining the humus and nutrients in soil, for activation of chemical and biological processes and last but not the least to maintain weed control. Choosing the most suitable system of vineyards floor management (middle rows, undervine, around vineyard) is a major problem which depends on preserving or enhancing soil fertility, improvement or worsening the soil physical, chemical and biological characteristics, ensuring water from soil and weed control. The experimental variants consisted of different practices of soil tillage, as follows: V1-bare row middles and grass strips/bare soil under vine; V2-bare soil/herbicides treatment under vine; V3bare row middles/bare soil under vine; V4-bare row middles with ripped soil/bare soil undervine; V5- raw middles and grass strips/manual hoeing under vine; V6-bare row middles/rotary hoe under vine; V7-raw middles and grass strips/herbicides treatment under vine. Observations were made on 'Burgund' cultivar regarding buds viability, grape production, yield quality and sugar content. The highest yield per hectare was achieved in the soil with bare raw middles prepared with rotary hoe under vine (V6). On soils with moisture deficiency and a high content of clay, vineyards floor management is recommended to be maintained both under vine and on raw middles, as well with the adjustable rotary tiller.
\end{abstract}

Keywords: buds viability, climate change, yield, tillage, viticulture

\section{Introduction}

Viticulture and winemaking is practiced since ancient times in areas where climate and soil conditions for growing vines are most favorable (Tesic et al., 2007). The association between wine quality and environmental factors has been widely researched and extensively discussed. Among the three most important factors (climate, soil and physiology), soil is the second decisive factor in grape production and last but not the least has a significant influence on wine quality (Petru et al., 2013a).

In many regions, soil plays a crucial role. Sequin (1986) claimed that the quality of wine produced in Bordeaux and Médoc regions is primarily due to the soil. Growers often associate grapes and then wine quality, with the type of soil on which the yield has been obtained (Carbonneau and Casteran, 1987a, 1987b; Gregory, 1963; Peynaud and Ribereau-Gayón, 1971; Rankine et al., 1971). Location and soil management are fundamental for a high quality vineyard. The most suitable locations for vineyards are those with well-structured soils, with optimum fertility and humidity, in order to provide a favourable environment for the root system development of the vines (Ohmart, 2011).

Vineyard floor management technique has an influence on the grapevine growth, weed management, soil conservation, disease attack and wine composition (Murisier and Beuret, 1986; Guerra and Steenwerth, 2012). In conservation tillage, more than $30 \%$ of crop residues are left on surface (Steenwerth and Belina, 2008) which offers the following benefits: reduces soil erosion, reduces labour, saves time and fuel, improves soil tilth, increases organic matter, traps soil moisture to improve water availability, improves water and air quality (Busari et al., 2015). Even in traditional use of conventional tillage less then $30 \%$ of the crop residues are left on the surface so that to reduce the carbon quantity that enters into the soil. Besides the fact that this technology leads to higher production of $\mathrm{CO}_{2}$, it is highly required for fossil fuels (Gómez et al., 2011). When no-till technique is chosen there is no disturbance of the soil surface, which allow carbon to enter into the soil organic matter; consequently, a smaller amount of fuel is required and the production of $\mathrm{N}_{2} \mathrm{O}$ migh be higher (Glenn et al., 2011).

The importance of vineyard floor management systems is becoming more and more conspicuous in recent years due to climate change; atypical alternations of dry periods with some deficient precipitation, periods of excessive heat, including temperature drop-off during June and July, require a better management of ground water resources (Cass and Baumgartner, 2011). Therefore, viticultural research should always search for appropriate solutions for soil maintenance in order to avoid both excess water and water scarcity, depending on the specifications of each period (Trégoat et al., 2002; Van Leeuwen et al., 2004). 


\section{Materials and Methods}

\section{Study area and the aim of the research}

This research was carried out between 2011-2013 in a vineyard of the didactic and research station of Banat's University of Agricultural Sciences and Veterinary Medicine "King Michael I of Romania". The study area is situated in the West part of Romania, in a well-known Romanian Viticultural Area (Banat region). The aim of the research was to evaluate different types of floor management in the vineyard in order to reduce the percentage of manual labour.

\section{Biological material and experimental procedure}

The experiment was organized in a completely randomized design with eight treatments, three repetitions each. The experiment was carried out on 'Burgund' variety, which is included in the top red wine varieties cultivated in the Western part of Romania. The objectives of the study were to establish the correlations between the experimental variants, bud viability-in the context of climate change, as well as to investigate the impact of different technologies upon quantity and quality of production. The vineyard floor management was different for experimental variants, as follow:

$\mathrm{V}_{1}$ - row middles and grass strip/bare soil by tillage under vine (tractor and adjustable offset rotary tiller);

$\mathrm{V}_{2}$ - bare soil by tillage floor between vines (cultivator)/herbicides treatment under vine;

$\mathrm{V}_{3}$ - bare row middles soil tillage (cultivator)/bare soil by tillage under vine (tractor and adjustable offset rotary tiller);

$\mathrm{V}_{4}$ - bare row middles with ripped soil (tractor and ripper)/bare soil tillage under vine (tractor and adjustable offset rotary tiller);

$\mathrm{V}_{5}$ - raw middles and grasses strip/manual hoeing under vine;

$\mathrm{V}_{6}$ - bare row middles soil tillage (tractor and rotary hoe)/rotary hoe undervine (tractor and adjustable offset rotary tiller);

$\mathrm{V}_{7}$ - raw middles and grass strips/herbicides treatment undervine.

\section{Statistical procedures}

For the correctness of the results, all data were analyzed by statistical methods using 2015 GraphPad Software Inc., Prism 6 for Windows. Student's $t$ test with least significant difference (LSD) was calculated at the $5 \%$ significance level to facilitate the comparison between treatment means.

\section{Results and Discussion}

Knowledge of the phenological characteristics of the viticultural system is very important whereas the optimal development of fruit quality for wine production is linked to the system. Analyzing the data of three experimental years, the influence of vineyard floor management system on row-middle and rows of vines, on the number of viable buds in 'Burgund' variety (Table 1), it was found that control was exceeded significantly the sixth variant (V6) where the soil was tilled rowmiddle/rotary hoe undervine, with an average of 463.33 viable buds (92.66\%).

The higher percentage of viable buds might be due to the rotary hoeing that mince and mix the soil, thus increasing the space for air and in the same time destroying the small weeds that are competing with the vines for soil nutrients. However, there are also negative effects on the environment to be considered, as the technique can produce more dust due to blades high speed, therefore it is necessary to properly estimate the overall effects.

The most underperforming soil maintenance was observed in the raw-middle grass correlated with herbicides in the vine row $\left(V_{7}\right)$, which had an average of 405 viable buds, only $81 \%$ of the total, showing a significant difference from the control. The lowest number of viable buds could be due to perennial grasses, that are know to be very competitive with grape vine roots for nutrients and water, or because a permanent sward, lowersoil and canopy temperatures (Petru et al., 2013b).

Variants with raw-midle grass and under vine tillage, with an average of $420(84 \%)$ viable bud eyes (V1), raw-middle tillage and herbicides in the vine rows variant, with 426.66 viable eyes in average, respectively $85.33 \%(\mathrm{~V} 2)$ and raw-middle scarifying (tractor and adjustable offset rotary tiller) correlated with under vine tillage variant, with an average of 440 viable bud eyes (88\%) (V4), have not recorded statistical significance compared to control.

Yields during 2011-2013, expressed in $\mathrm{kg} / \mathrm{ha}$, are presented in Table 2. Data table show that raw-middle and under vine bare soil $\left(V_{6}\right)$ treatment had the highest positive response. $V_{3}$ and $V_{4}$ had significantly higher yield than control, while raw midddle grass $\left(\mathrm{V}_{7}\right)$ consistently showed a significantly lower yield than the other treatments. Van Huyssteen and Weber (1980) have come to the same conclusion in their study concerning permanent row-middle sward.

High canopy vigour and fruit yield favoured by a high number of viable buds can influence wine quality, depending upon fruit's ripeness and climate (Ingels et al., 2005).

Table 1. Variants of soil maintenance influence on buds viability at 'Burgund' variety (averages for 2011-2013 period)

\begin{tabular}{|c|c|c|c|c|c|c|c|}
\hline \multirow[b]{2}{*}{ Variant } & \multirow[b]{2}{*}{ Total buds } & \multicolumn{2}{|c|}{ Viable buds } & \multicolumn{2}{|c|}{ Dead buds } & \multirow{2}{*}{$\begin{array}{l}\text { Difference to } \\
\text { control } \\
\text { (viable buds) }\end{array}$} & \multirow[b]{2}{*}{ Significance } \\
\hline & & No. & $\begin{array}{c}\% \\
\text { of total }\end{array}$ & No. & $\begin{array}{c}\% \\
\text { of total }\end{array}$ & & \\
\hline $\mathrm{V}_{1}$ & 500 & 420.0 & 84.0 & 80.0 & 16.0 & -2.2 & - \\
\hline $\mathrm{V}_{2}$ & 500 & 426.6 & 85.3 & 73.3 & 14.7 & -0.9 & - \\
\hline$V_{3}$ & 500 & 451.7 & 90.3 & 48.3 & 9.6 & +4.1 & * \\
\hline $\mathrm{V}_{4}$ & 500 & 440.0 & 88.0 & 60.0 & 12.0 & +1.8 & - \\
\hline$V_{5}$ & 500 & 411.6 & 82.3 & 88.3 & 17.6 & -3.9 & o \\
\hline $\mathrm{V}_{6}$ & 500 & 463.3 & 92.6 & 36.7 & 7.3 & +6.4 & $* *$ \\
\hline $\mathrm{V}_{7}$ & 500 & 405.0 & 81.0 & 95.0 & 19.0 & -5.2 & oo \\
\hline $\begin{array}{l}\text { Mean } \\
\text { (Control) }\end{array}$ & 500 & 431.1 & 86.2 & 68.8 & 13.8 & - & - \\
\hline
\end{tabular}


502

Table 2. Average production per hectare obtained at 'Burgund' variety (2011-2013)

\begin{tabular}{|c|c|c|c|c|}
\hline \multirow{2}{*}{ Variant } & \multicolumn{2}{|c|}{ Yield } & \multirow{2}{*}{$\begin{array}{c}\text { Difference to control } \\
(\mathrm{kg} / \mathrm{ha})\end{array}$} & \multirow{2}{*}{ Significance } \\
\hline & $\mathrm{kg} / \mathrm{ha}$ & $\%$ & & \\
\hline $\mathrm{V}_{1}$ & 9548 & 95.5 & -447 & - \\
\hline $\mathrm{V}_{2}$ & 10027 & 100.3 & +32 & - \\
\hline $\mathrm{V}_{3}$ & 10742 & 107.5 & +747 & ** \\
\hline $\mathrm{V}_{4}$ & 10682 & 106.9 & +687 & ** \\
\hline $\mathrm{V}_{5}$ & 9055 & 90.6 & -940 & oo \\
\hline $\mathrm{V}_{6}$ & 11171 & 111,8 & +1176 & $* * *$ \\
\hline $\mathrm{V}_{7}$ & 8742 & 87.5 & -1253 & ooo \\
\hline Mean (Control) & 9995 & 100.0 & - & - \\
\hline
\end{tabular}

LSD 5\% $=503 ;$ LSD $1 \%=683 ;$ LSD $0.1 \%=1075$

Table 3. Grape juice sugar content at 'Burgund' variety (averages for 2011-2013)

\begin{tabular}{|c|c|c|c|c|}
\hline \multirow{2}{*}{ Variant } & \multicolumn{2}{|c|}{ Sugar content } & \multirow{2}{*}{ Difference to control (g/l) } & \multirow{2}{*}{ Significance } \\
\hline & $\mathrm{g} / \mathrm{l}$ & $\%$ & & \\
\hline $\mathrm{V}_{1}$ & 191.3 & 98.1 & -3.7 & o \\
\hline $\mathrm{V}_{2}$ & 197.3 & 101.1 & +2.3 & - \\
\hline $\mathrm{V}_{3}$ & 198.6 & 101.8 & +3.6 & * \\
\hline $\mathrm{V}_{4}$ & 198.6 & 101.8 & +3.6 & * \\
\hline $\mathrm{V}_{5}$ & 190.3 & 97.6 & -4.7 & o \\
\hline $\mathrm{V}_{6}$ & 200.0 & 102.5 & +5.0 & $*$ \\
\hline $\mathrm{V}_{7}$ & 189.0 & 96.9 & -6.0 & o \\
\hline Mean (Control) & 195.0 & 100.0 & - & - \\
\hline
\end{tabular}

Grapes or grape juice sugar content is an important indicator to determine fruit maturity. Average results for the grapes sugar content in the three experimental years are shown in Table 3 . The amount of sugar in the grape juice varied between 150 and $250 \mathrm{~g} / \mathrm{l}$. In unripe berries, the dominant sugar was glucose. At ripening, glucose and fructose were present in equal proportion $s(1: 1)$. In the ripe berries, fructose concentration was higher than glucose.

The lower limit of the average sugar content in grape juice was $189 \mathrm{~g} / \mathrm{l}$ in variant $\mathrm{V}_{7}$ with herbicides treatment applied under vine and row-middle grass, while the maximum value was $200 \mathrm{~g} / \mathrm{l}$ in juice resulting from grapes harvested in the sixth variant with bare soil prepared by rotary hoe row middle and under vine.

A significant difference was registered compared to control for the average sugar content in grape juice obtained in variant three and four, both with $+3.6 \mathrm{~g} / \mathrm{l}$ and in the sixth variant with $+5 \mathrm{~g} / \mathrm{l}$. During the experimental years variants with row-middle grass and bare soil $\left(V_{1}\right)$, manual hoeing $\left(V_{5}\right)$, or herbicides application $\left(V_{7}\right)$ under vine, have registered lower average sugar content in grape juice. For this productive parameter, no significant differences were observed compared to control.

Time of harvest can influence the solvent water from grape berries (Matthews and Nuzzo, 2007) and consequently the sugar content. Fruits harvested in the afternoon contain less solvent water then those harvested later in the evening. Matthews and Nuzzo (2007) also reported that sugar content in the grapes from their project was directly proportional to berry size.

Viable buds, grape yield and sugars in all experimental variants were clearly identified in order to note the differences for each of the three components (Fig. 1).

Results for all the three components in the experimental variants have shown a similar pattern: $V_{6}$ variant showed the highest values, while the lowest were found within $V_{7}$. The

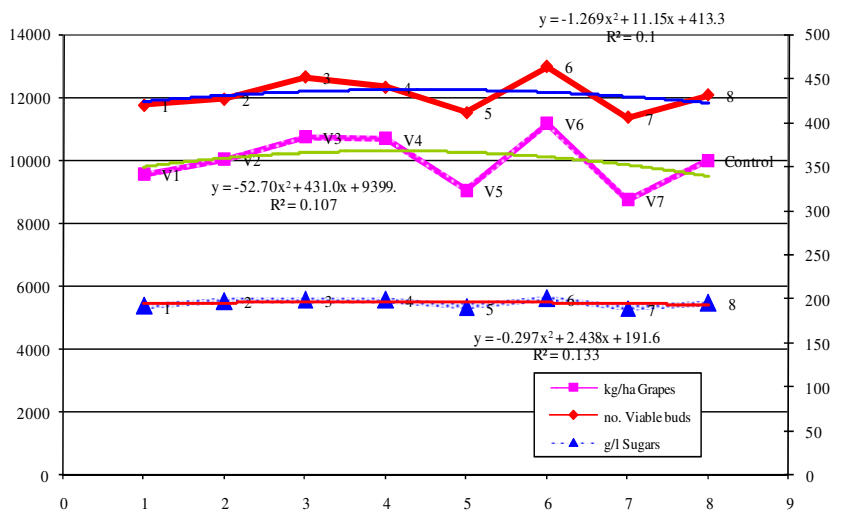

Fig.1. Yield, viable buds and sugars (g/l) change according to different soil tillage

yield increased in $\mathrm{V}_{6}$ without cover crop; this might have been due to the tillage, which promoted shoot growth and berry development. Tesic et al. (2007) confirmed that grape yield was significantly affected by cover crops, while bare soil rows had greater yield than cover crop rows. Palliotti et al. (2007) showed that cover crops reduced yield compared to bare soil up to 2.3, t ha ${ }^{-1}$. Hostetler et al. (2007) also suggested that excessive weed competition reduced yield and fruit quality. Instead Hanna et al. (1995) did not found cover crops affecting grape yield, but they reported greater berry weight as a result of cover crop use.

Opinions regarding different soil maintenance systems used in vineyards are divergent. Some research have shown that the row middles grass lead to lower production, as stated by Van Huyssteen and Weber (1980), in the light of the results from Chenin Blanc grown on a medium textured soil. It is considered that the use of permanent crops and natural vegetation rows middles decrease the vigor of the vine (Bramley et al., 2011). 
According to Pinamonti et al. (1996) statement, permanent crops can lead to a significant decrease in the concentration of nitrogen in young leaves, but at the same time increase the amount of $\mathrm{P}$ and $\mathrm{K}$ as compared to chemical control of weeds or bare soil practicing (Sicher et al., 1993). Buckerfield and Webster (1996) found that grape production, when using straw mulch row middles and herbicides under vine, was significantly higher than yields per hectare by using bare soil practice.

The influence of grapevine floor management treatments on sugar content from grape juice was low and insignificant. Palliotti et al. (2007) in their exploration concerning the effects of tillage and permanent cover crops on grape yield quality founded that cover crops influenced sugar content. It should be mentioned that the metabolism of the berry was changed after veraison, the sugars accumulation being favoured (Lizana et al., 2007).

Floor management practices have shown the influence on the yield, whereas the increase of vegetative cover may also have a negative impact on grapevine performance (Eldona and Gershenson, 2015).

\section{Conclusions}

Vineyard floor management has the potential to influence soil and grapevine parameters. Results obtained in 'Burgund' variety showed that the highest yield, sugar content and buds viability corresponded to $V_{G}$, respectively floor management system. Neither cover crop treatments nor herbicide treatments significantly influenced grape yield, excepting the bare soil. The optimal sugar content $(200 \mathrm{~g} / \mathrm{l})$ was achieved at the yield of $11,171 \mathrm{~kg} / \mathrm{ha}$, with very significant diffrences between the yields of other variants. Although results were positive for $V_{6}$, data did not definetly prove which is the optimal load of grapes for the best wine quality. Wheather conditions correlated with experimental variants influenced the crop load, grape juice sugar content and grape yield. Cover crops contributed to the improvement of the physical and chemical characteristics of the soil, weed suppression, vine vigour or crop load, which may lead to an economic benefit due to the nitrogen that slowly infiltrates into the soil, stimulating the early canopy development and yield. Results indicate that further studies are recommenrde in order to identify the relationship between environmental factors: experimental variants and buds viability, grape yield and grape juice sugar content. Further studies must include also the economics behind these floor management practices.

\section{References}

Bramley RGV, Ouzman J, Boss PK (2011). Variation in vine vigour, grape yield and vineyard soils and topography as indicators of variation in the chemical composition of grapes, wine and wine sensory attributes. Australian Journal of Grape and Wine Research 17(2):217-229.

Buckerfield JC, Webster KA (1996). Earthworms, mulching, soil moisture and grape yields: earthworm response to soil management practices in vineyards, Barossa Valley, South Australia. Australian and New Zealand Wine Industry Journal 11(1):47-53.
Busari MA, Kukal SS, Kaur A, Bhatt R, Dulazi AA (2015). Conservation tillage impacts on soil, crop and the environment. International Soil and Water Conservation Research 3(2):119-129.

Carbonneau AP, Casteran P (1987a). Interactions 'training system $\mathrm{x}$ soil $\mathrm{x}$ rootstock' with regard to vine ecophysiology, vigour and red wine quality in the Bordeaux area. Acta Horticulturae 206:119-140.

Carbonneau AP, Casteran P (1987b). Optimizations of vine performance by the lyre training systems. Proceedings of the sixth Australian Wine Technical Conference. Lee T (Ed) pp 194-204.

Cass A, Baumgartner K (2011). Soil health and wine quality: how vine health and fruit quality are influenced by soil properties. In: Blair RJ, Lee TH, Pretorius IS (Eds). Proceedings of the 14th Australian Wine Industry Technical Conference, Adelaide 2010 pp 226-235.

Eldona J, Gershenson A (2015). Effects of cultivation and alternative vineyard management practices on soil carbon storage in diverse Mediterranean landscapes: a review of the literature. Agroecology and Sustainable Food Systems 39(5):516-550.

Glenn T, McGourty JO, Chaney D (2011). Organic winegrowing manual. UCANR Publications pp 62-63.

Gómez GómezJA, Llewellyn C, Basch G, Sutton PB, Dyson JS, Jones CA (2011). The effects of cover crops and conventional tillage on soil and runoff loss in vineyards and olive groves in several Mediterranean countries. Soil Use and Management 27(4):502-514.

Gregory GR (1963). Soil requirements for grapegrowing. Agricultural Gazette of New South Wales 74:434-438, 465-467.

Guerra B, Steenwerth K (2012). Influence of floor management technique on grapevine growth, disease pressure, and juice and wine composition: a review. American Journal of Enology and Viticulture 63(2):149164.

Hanna R, Zalom FG, Clyde L (1995). Integrating cover crops into grapevine pest and nutrition management: The transition phase. Sustainable Agriculture Technical Reviews 7(3):11-14.

Hostetler GL, Merwin IA, Brown MG, Padilla-Zakour O (2007). Influence of undervine floor management on weed competition, vine nutrition, and yields of Pinot Noir. American Journal of Enology and Viticulture 58(4):421430.

Ingels CA, Scow KA, Whisson DA, Drenovsky RE (2005). Effects of cover crops on grapevines, yield, juice composition, soil microbial ecology, and gopher activity. American Journal of Enology and Viticulture 56(1):19-29.

Lizana LA, Garcia de Cortazar V, Pinto M, Miranda J (2007). Effect of night temperatures on Thompson seedless soluble solids and acidity evolution and berry growth. Acta Horticulturae 754:191-196. 
504

Matthews MA, Nuzzo V (2007). Berry size and yield paradigms on grapes and wines quality. Acta Horticulturae 754:423-435.

Murisier F, Beuret E (1986). L'enherbement des sols viticoles. Revue Suisse de Viticulture, Arboriculture, Horticulture 18(5):291-294.

Ohmart CP (2011). View from the vineyard: A practical guide to sustainable winegrape growing. Wine Appreciation Guild: San Francisco.

Palliotti A, Mattioli S, Berrios JG, Silvestroni O, Cartechini A, Petoumenou D (2007). Long-term effects of seeded covercrop on vegetative characteristics, yield and grape and wine composition of 'Grechetto' grapevines in Central Italy. Acta Horticulturae 754:515-520.

Petru A, Dobrei A, Dobrei A, Boc R (2013 a). Research concerning the evolution of yield in some grape varieties by applying different vineyard floor management systems. Journal of Horticulture, Forestry and Biotechnology 17(3):36-42.

Petru A, Dobrei A, Dobrei A, Nistor E (2013 b). Influence of variants floor management on the buds viability in Silvania variety. Journal of Horticulture, Forestry and Biotechnology 17(3):43-47.

Peynaud E, Ribereau-Gayon P (1971). The Grape. In: Hulme AC (Ed). The biochemistry or fruits and their products. Academic Press, London pp 171-205.

Pinamonti F, Stefanini M, Dalpiaz A (1996). Soil management effects on nutritional status and grapevine performance. Wein-Wissenschaft 51(2):76-82.

Rankine BC, Fornachon JCM, Boehm EW, Cellier KM (1971). Influence of grape variety, climate and soil on grape composition and on the composition and quality of table wines. Vitis 10:33-50.
Sequin G (1986). Terroirs and pedology of vine growing. Experientia 42:861-873.

Sicher L, Dorigoni A, Stringari G (1993). Soil management effects on nutritional status and grapevine performance. Mineral Nutrition of Deciduous Fruit Plants 383:73-82.

Steenwerth K, Belina KM (2008). Cover crops enhance soil organic matter, carbon dynamics and microbiological function in a vineyard agroecosystem. Applied Soil Ecology 40(2):359-369.

Tesic D, Keller M, Hutton RJ (2007). Influence of vineyard floor management practices on grapevine vegetative growth, yield, and fruit composition. American Journal of Enology and Viticulture 58(1):1-11.

Trégoat O, Van Leeuwen C, Choné X, Gaudillère JP (2002). Étude du régime hydrique et de la nutrition azotée de la vigne par des indicateurs physiologiques. Influence sur le comportement de la vigne et la maturation du raisin (Vitis vinifera L. cv 'Merlot', 2000, Bordeaux). Journal international des sciences de la vigne et du vin / International Journal of Vine and Wine Sciences 36(3):133-142.

Van Huyssteen L, Weber HW (1980). The effect of selected minimum and conventional tillage practices in vineyard cultivation on vine performance. South African Journal of Enology and Viticulture 1(2):77-83.

Van Leeuwen C, Friant P, Choné X, Trégoat O, Koundouras $S$, Dubourdieu D (2004). Influence of climate, soil and cultivar on terroir. American Journal of Enology and Viticulture 55(3):207-217. 